\title{
Low Grade Chronic Inflammatory Response in Pathogenicity of Diabetes Mellitus
}

\author{
Shamim Shaikh Mohiuddin* \\ Department of Biochemistry, Imam Abdulrahman Bin Faisal University, Saudi Arabia
}

Submission: January 20, 2018; Published: January 29, 2018

*Corresponding author: Shamim Shaikh Mohiuddin, Department of Biochemistry, College of Medicine, Imam Abdulrahman Bin Faisal University, Dammam, Saudi Arabia, Tel: 0096-656-253-9936; Email: smohiuddin@iau.edu.sa

\begin{abstract}
Acute phase reaction which is mainly cytokine-mediated is observed to be closely involved in the pathogenesis of type 2 diabetes. Since maximum world populations are at elevated risk of developing diabetes, we tested this hypothesis by estimating circulating acute phase proteins in type 1(T-1), type 2 (T-2) diabetic patients and type 2 diabetic patients under oral hypoglycemic drugs for duration of at least 5 years.

The acute phase proteins, $\alpha 1$ - antitrypsin, $\alpha 1$ - acid glycoprotein, ceruloplasmin and fibrinogen were estimated in the plasma in newly diagnosed 12 T-1 cases, newly diagnosed 25 T-2 cases and 25 T-2cases under oral hypoglycemic agent for at least 5 years Thirty normal controls to match the age and sex of the test groups were also studied. The levels of these proteins were correlated with their BMI and random plasma glucose values.

In comparison with the controls, the values of all the four proteins studied were significantly elevated in T- 1 patients and T- 2 patients $(\mathrm{p}<.00001)$ and reduced significantly except $\alpha 1$ - acid glycoprotein and ceruloplasmin. Interestingly, no correlation was found with BMI or the degree of hyperglycemia in either of the types. A low grade inflammatory process is definitely implicated in the pathogenesis of type 2 diabetes and even type 1 diabetic patients. This line of pathological basis should be further explored for diagnosis, management and follow up.
\end{abstract}

Keywords: Chronic inflammation; Diabetes mellitus; Acute phase reaction

\section{Introduction}

Diabetes Mellitus is a syndrome with disordered metabolism and inappropriate hyperglycemia due to either deficiency of insulin secretion or to a combination of insulin resistance and inadequate insulin secretion to compensate [1]. Although hyperglycemia is the main characteristic of all form of diabetes mellitus, the pathogenic mechanism by which hyperglycemia arises differs widely. Some forms of Diabetes mellitus are characterized by an absolute insulin deficiency or a genetic defect leading to defective insulin secretion; where as other forms share insulin resistance as their underlying etiology [1]. Recently, there in increasing evidence that an ongoing cytokine induced acute phase response which is sometimes called low grade inflammation, but part of a widespread activation of the innate immune system, is closely involved in the pathogenesis of type 2 diabetes mellitus and associated complications such as dyslipidemia and atherosclerosis. Elevated circulatory inflammatory markers such as C-reactive protein and interleukin-6 predict the development of type 2 Diabetes mellitus and several drugs with anti-inflammatory properties both lower both acute phase reactants and glycemia and possibly decrease the risk of developing type 2 diabetes mellitus. Age, inactivity, certain dietary components, smoking, psychological stress and low birth weight are among the risk factors for type 2 diabetes mellitus, which are also known to be associated with activated innate immunity. Activated immunity may be the common antecedent of developing type 2 diabetes mellitus [2].

This recent explosion of interest in the notion that chronic low-grade inflammation and activation of the innate immune system are closely involved in the pathogenesis of type 2 diabetes mellitus was first proposed in 1997-98 [3]. Several studies after that have shown that circulating markers of inflammation, acute phase reactants or interleukin-6 (IL-6) are strong predictors of the development of type 2 diabetes $[4,5]$. The role of acute phase reactants in the development of type 1 diabetes mellitus is not very clear. $\alpha 1$-acid glycoprotein, $\alpha-1$ antitrypsin, fibrinogen and ceruloplasmin are few of the acute phase reactants. The level of these inflammatory markers in the pathogenesis of type 1 and type 2 Diabetes mellitus was of interest. 


\section{Current Research in Diabetes \& Obesity Journal}

Material and Methods

\section{Study design}

Following four groups of subjects were selected for present study:

A. 12 newly diagnosed untreated type 1 diabetes mellitus patients

B. 25 newly diagnosed untreated type 2 diabetes mellitus patients within the age limit of $30-60$ years

C. 25 type 2 diabetes mellitus patients who are under treatment of oral hypoglycemic drugs for at least 5 yrs between the age limit of 30-60 yrs.

D. 30 nondiabetic healthy controls.

Height and weight of all subjects were recorded, and body mass index was calculated. None of the ninety-two volunteers were alcoholics or smokers. The participants did not suffer from chronic inflammatory diseases like asthma, chronic bronchitis, and rheumatoid arthritis as was ascertained by clinical history. Informed consent was taken from the individual subjects prior to blood collection. The study was approved by institutional ethical committee.

The following methods were followed for determination of each of the parameters.

\section{Blood glucose estimation}

Blood glucose was estimated with Agappe manual diagnostic kit by GOD-POD methodology. The enzymatic procedure of Trinder P was followed [6]. Glucose is oxidized by glucose oxidase to gluconic acid and H2O2. Hydrogen peroxide in presence of phenol and 4-amino antipyrine is acted upon by peroxidase to form red quinine. The absorbance of colored compound was measured at $532 \mathrm{~nm}$.

\section{Fibrinogen assay}

Fibrinogen assay in plasma was carried out by Biuret method [7]. Fibrinogen present in the plasma is converted to fibrin in presence of calcium chloride. The fibrin clot formed is collected and then digested with $\mathrm{NaOH}$. Protein content of the clot is determined using a red filter. $0.5 \mathrm{ml}$ of plasma was mixed with 14 $\mathrm{ml}$ of distilled water and $0.5 \mathrm{ml}$ of $2.5 \%$ calcium chloride solution in a small beaker and incubated at $37^{\circ} \mathrm{C}$ until a clot was formed. Then a glass rod was rotated to collect the clot on to it. The rod was pressed against the side of the beaker to squeeze out any solution and to compress the clot. Care was taken to pick up any small piece of clot on the rod, which may have become detached and was dried by pressing carefully against a filter paper. Then it was transferred into a test tube into which the digestion was to be carried out.

After that, the clot was digested with $0.5 \mathrm{ml}$ of $0.1 \mathrm{~N} \mathrm{NaOH}$ in a boiling water bath. After cooling, $3.5 \mathrm{ml}$ of working Biuret reagent was added to the tube. The OD of the blue color developed was read at $555 \mathrm{~nm}$ after standing the tube in a water bath at $37^{\circ} \mathrm{C}$ for 5 minutes. $0.5 \mathrm{ml}$ of standard protein solution $(800 \mathrm{mg} / \mathrm{dl})$ and $0.5 \mathrm{ml}$ of distilled water as blank were treated similarly.

\section{Estimation of serum ceruloplasmin}

Ceruloplasmin assay in serum was carried out by the method of Sunderman et al. [8]. At pH 5.4, ceruloplasmin catalyzes the oxidation of PPD to yield a coloured product which is believed to correspond either to Bandrowski's base or to Weurster's red. The rate of formation of colored oxidized product is proportional to the concentration of ceruloplasmin, if, a correction is made for the nonenzymatic oxidation of PPD. Therefore, simultaneous assay were carried out with and without sodium azide, which inhibited the enzymatic oxidation of PPD. The difference between the results of the two assays is proportional to ceruloplasmin concentration.

\section{Estimation of $\alpha 1$-antitripsin}

$\alpha-1$ antitrypsin assay in serum was carried out by the modified method described by Sundaresh et al. [9]. The Proteolytic enzyme trypsin hydrolyses casein, with the formation of smaller peptides. The enzyme reaction after suitable interval of time is arrested by the addition of TCA which precipitated the protein, but the peptides are soluble in the acid. The TCA soluble fragments are a measure of Proteolytic activity of the enzyme. When the inhibitor is added to the preincubated mixture, it prevents the release of peptides by the Proteolytic enzymes. Thus, the estimation of TCA soluble components in the presence and absence of inhibitor is a measure of inhibitory activity against Proteolytic enzymes. The TCA soluble fragments are analyzed by the method of Lowry. The final color formed is a result of Biuret reaction of the peptides with copper ions in alkali and reduction of the phosphomolybdic acid reagent by the presence of tyrosine and tryptophan which are present in the treated peptides.

\section{Determination of serum $\alpha-1$ acid glycoprotein}

$\alpha-1$ acid glycoprotein assay in serum was carried out by the method of Winzler RJ et al. [10]. After removing heat coagulable proteins with perchloric acid, the orosomucoid which remains in the solution is precipitated by phosphotungstic acid and estimated by determining it carbohydrate content by reaction with an orcinol-sulphuric acid reagent, or its nitrogen by Kjeldahl nesslerization or its tyrosine content using FolinCiocalteau reagent.

\section{Result}

The anthropometric data of the subjects participated in the study are presented in Table 1.

\section{Discussion}

The aim of this study was to examine inflammation as a 


\section{Current Research in Diabetes \& Obesity Journal}

pathogenetic causeof type 2 diabetes mellitus. Twenty-five type 2 newly diagnosed patients showed increased levels of $\alpha 1$ antitrypsin, $\alpha 1$-acid glycoprotein, ceruloplasmin and fibrinogen. The findings were in agreement with most of the authors who worked with acute phase proteins in type 2 diabetes [11-13]. The role of chronic low-grade inflammation in the pathogenesis of type 2 diabetes seems possible beyond doubt. The course of the disease and resulting complications are similar in both type 1 and type 2 diabetes. The most dreaded complication being that of development of atherosclerosis resulting in cardiovascular diseases. Fibrinogen is identified as an independent risk factor in the development of ischemic heart diseases [14]. Irrespective of the patients being type 1 or type 2 , the risk of developing atherosclerosis remains the same. Hence there must be some mechanism which links the pathogenecity of type 1 and type 2 diabetes. Barrazzani et al. [15] infused insulin to non-diabetics, type 1 and type 2 diabetics and studied its role in fibrinogen production. Insulin replacement activity suppressed fibrinogen production in non-diabetics and type 1 diabetic individuals.
Fibrinogen production and its plasma concentration increased in insulin resistant type 2 diabetics when euglycemia and euaminoaciduria were maintained. They postulated that an altered response to insulin causes hyperfibrinogenemia in type 2 diabetic patients. If this hypothesis holds well, it doesn't explain hyperfibrinogenemia in type 1 diabetics where the basic pathology is insulin deficiency. Hence there must be some other factors which stimulate increased fibrinogen synthesis in type 1 patients contributing to cardiovascular disease risk. An insulin resistance syndrome score [16] was developed based on clinical risk factor in patient with type 1 diabetes and validated using euglycemic-hyperinsulinemic clamp studies. Fibrinogen levels were significantly associated with this insulin resistance syndrome score. This may explain high fibrinogen level in type 1 diabetes. But it still does not answer the above findings since the type subjects in this study were newly diagnosed. Hence the mechanism of increased fibrinogen synthesis needs to be proved further.

Table 1: Anthropometric data of Group I, GrouP II, GrouP III and Group IV.

\begin{tabular}{|c|c|c|c|c|}
\hline & $\begin{array}{c}\text { Group I }(\mathbf{n}=\mathbf{1 2}) \\
(\text { Mean } \pm \text { SD) }\end{array}$ & $\begin{array}{c}\text { Group II (n=25) } \\
\text { (Mean } \pm \text { SD) }\end{array}$ & $\begin{array}{c}\text { Group III (n=25) } \\
\text { (Mean } \pm \text { SD) }\end{array}$ & $\begin{array}{c}\text { Group IV (n=30) } \\
\text { (Mean } \pm \text { SD) }\end{array}$ \\
\hline Age (yrs) & $18.33 \pm 7.64$ & $48.22 \pm 7.11$ & $51.32 \pm 7.56$ & $44.97 \pm 15.06$ \\
\hline BMI & $19.50 \pm 1.23$ & $24.03 \pm 1.46$ & $24.20 \pm 2.40$ & $21.75 \pm 2.27$ \\
\hline
\end{tabular}

Group I: Type 1 diabetes mellitus patient (newly diagnosed)

Group II: Type 2 diabetes mellitus patient (newly diagnosed)

Group III: Type 2 diabetes mellitus patient (under treatment for at least 5 years)

Group IV: Control

$\mathrm{n}=$ Number of Subjects; SD: Standard Deviation; BMI: Body Mass Index

Ceruloplasmin is known to have antioxidant action [17]. It is also an acute phase protein with a response of intermediate magnitude. Ceruloplasmin is known to stimulate cell proliferation and angiogenesis [18]. The higher levels of ceruloplasmin in both in type 1 and type 2 as compared to controls may be due to an oxidative stress that is prevalent in both types of diabetes [19,20]. Ehrenwald [21] showed a very interesting feature of ceruloplasmin. The intact human ceruloplasmin which is $132 \mathrm{KD}$ molecules caused increased oxidation of LDL in vitro. Starkebaum \& Harlan et al. [22] also showed that increased serum ceruloplasmin could generate excess oxidized LDL, and cause vascular injury by generating free radicals such as hydrogen peroxide [22]. These findings defined the earlier notions of the antioxidant activity of ceruloplasmin. By further investigations Ehrenwald et al. [21] found that the holoceruloplasmin, which is seen in serum as a $132 \mathrm{KD}$ molecule, has a prooxidant effect and the action was attributed to the copper ions present in ceruloplasmin. The commercially available ceruloplasmin is a degraded product containing either 115KD fragment or 19KD fragment or both. These had an antioxidant effect. The works done to show that ceruloplasmin as an antioxidant used these degraded products.
The antioxidant action of a commercial ceruloplasmin was observed even in the system where holoceruloplasmin oxidized LDL [23]. Hence considering ceruloplasmin as an antioxidant in vivo is debatable. The LDL oxidizing action of ceruloplasmin could probably explain at least in part of the increased risk of IHD in both type 1 and type 2 diabetes. Also, it could not be wrong to count ceruloplasmin as an acute phase reactant whose levels are increased in both the types of diabetes.

The values of various parameters when compared between the untreated type 1 patients and type 2 patients reveals a significant increase in type 2 patients. Even the ceruloplasmin values, although not statistically significant, were slightly higher in the type 2 patients. The mean random blood sugar (RBS) values in group 1 (Type 1 diabetes) patients was $338.25 \pm 50.97 \mathrm{mg} /$ $\mathrm{dl}$ and that of group II (Type 2 newly diagnosed diabetics) was $193.26 \pm 35.30 \mathrm{mg} / \mathrm{dl}$. Despite this huge difference, the inflammatory markers levels were higher in the type 2 patients which go to prove that the glycemic status doesn't influence the inflammatory markers. This is in accordance with previous findings $[24,25]$. Evidence is available to say that inflammatory markers are elevated well before the clinical manifestation of hyperglycemia [26-29]. This also gives credence to the thought 


\section{Current Research in Diabetes \& Obesity Journal}

that activation of innate immunity is not related to hyperglycemia. But research has shown that decreasing plasma glucose levels decrease the concentration of acute phase reactants [30]. Also $2 \mathrm{hrs}$ post load glucose values showed positive correlation with the inflammatory markers in few studies. $\alpha 1$-acid glycoprotein levels remained within normal limits in the type 1 patients whereas significant high levels were seen in the type 2 patients $(\mathrm{p}<0.0001)$. Although both type 1 and type 2 patients showed significant high $\alpha 1$-antitrypsin levels, the comparison between two groups also reached statistical significance $(p=0.003)$ with higher values in type 2 patients. The above findings can be best explained as insulin mediated increased synthesis of the hepatic proteins.

The underlying mechanism for the augmented acute phase response is not well understood and the stimulus for the response is unknown. Many hypotheses have been put forward and these include insulin resistance, obesity, atherosclerosis, other diabetic complications and maladaptation of the normal innate immune response to environmental threats [31-33]. The most widely studied is the association of obesity, insulin resistance, type 2 diabetes and acute phase reactants. It has been shown that adipocytes secret many proinflammatory cytokines in the postprandial state [34-36]. The term 'diabecity' has received attention [37] of late for obese diabetics. The 'common soil' theory proposed, evaluates the involvement of inflammation in the pathogenesis of diabetes and atherosclerosis. Hyperglycemia and insulin resistance could promote inflammation and inflammation may be a factor linking diabetes mellitus to the development of atherosclerosis. Elevated glucose levels promote inflammation by increasing oxidative stress [38], by the formation of AGEs and increased TNF (kappa B) [39]. In this study, the mean BMI was found to be $19.5 \pm 1.23$ in type 1 patient and $24.03 \pm 1.46$ in type 2 patients. No correlation was found between $\mathrm{BMI}$ and acute phase reactants. Hence it can be summarized that there could be multiple pathways involved in the activation of the innate immunity system and much work needed to be done to establish either a casual role in the development of mainly type 2 diabetes and could be type 1 diabetes also.

Having demonstrated that there is an inflammatory process going on in type 2 diabetes, we next thought of estimating inflammatory markers in patients on treatment (for at least 5 years) with oral hypoglycemic drugs. Many of the drugs have been shown to have anti-inflammatory effects. Statin drugs inhibits $\mathrm{HMG}-\mathrm{CoA}$ reductase and prevent atherosclerosis and inhibit the acute phase response by diminishing the deposition of LDL particles rich in cholesterol and phospholipids in macrophages and smooth muscle cells [40]. Statins were found to reduce CRP levels and did not correlate with the reduction of the lipid levels suggesting that the in addition to their ability to reduce LDL, statins may also inhibit the acute phase response [41]. Freeman et al. [40] showed that statin therapy also prevents diabetes mellitus. Pravastatin therapy in the West of Scotland Coronary Prevention Study resulted in a 30\% reduction of risk of developing type 2 diabetes. Salicylates in high doses have been known to lower glycosuria in diabetic patients. Although earlier studies were contradictory, these studies have used lower aspirin doses (<3gm/day) and therapeutic duration was only for a few days. Hundal [42] reported that high doses of aspirin (7gm/day) for 2 wks caused $25 \%$ reduction in fasting plasma glucose, $50 \%$ reduction in triglyceride and $15 \%$ reduction of CRP concentration independently of the changes in the plasma insulin concentration. The recently introduced oral hypoglycemic agents thiazolidinedions (Glitazone) are peroxizome proliferators activated receptor $\gamma$ (PRAR $\gamma$ ) agonist that have been regarded as insulin sensitizes through mechanisms such as altered transcription of insulin sensitive genes controlling lipogenesis, adipocytes differentiation, fatty acid uptake and GLUT 4 ( Glucose Transporter 4) expression. They also have an anti-inflammatory action inhibiting cytokine production, macrophage activation and reducing CRP as well as WBC count in type 2 diabetic subjects [43-46].

Table 2: Compares the mean values of all parameters between groups.

\begin{tabular}{|c|c|c|c|c|c|c|}
\hline \multirow{2}{*}{ Group } & \multirow{2}{*}{$\mathbf{n}$} & $\mathbf{R B S}(\mathbf{m g} / \mathbf{d l})$ & $\begin{array}{c}\boldsymbol{\alpha}-\mathbf{1} \text { Antitrypsin } \\
\mathbf{( m g / d l )}\end{array}$ & $\begin{array}{c}\boldsymbol{\alpha}-\mathbf{1} \text { Acid } \\
\text { glycoprotein } \\
\mathbf{( m g / d l )}\end{array}$ & $\begin{array}{c}\text { Ceruloplasmin } \\
(\mathbf{m g} / \mathbf{d l})\end{array}$ & $\begin{array}{c}\text { Fibrinogen } \\
(\mathbf{m g} / \mathbf{d l})\end{array}$ \\
\cline { 3 - 7 } & & Mean \pm SD & Mean \pm SD & Mean \pm SD & Mean \pm SD & Mean \pm SD \\
\hline Group I & 12 & $338.25 \pm 50.97$ & $495.70 \pm 32.77$ & $94.87 \pm 23.31$ & $40.69 \pm 9.85$ & $434.65 \pm 46.36$ \\
\hline Group II & 25 & $193.26 \pm 35.30$ & $562.16 \pm 63.00$ & $181.93 \pm 31.94$ & $45.05 \pm 9.03$ & $572.25 \pm 82.26$ \\
\hline Group III & 25 & $193.61 \pm 33.65$ & $519.38 \pm 47.80$ & $87.10 \pm 17.69$ & $25.73 \pm 9.94$ & $581.74 \pm 79.09$ \\
\hline Group IV & 30 & $94.20 \pm 7.00$ & $350.48 \pm 114.07$ & $103.41 \pm 22.13$ & $26.95 \pm 4.10$ & $335.34 \pm 42.19$ \\
\hline
\end{tabular}

$\mathrm{n}=$ Number of Subjects; SD: Standard Deviation; RBS: Random Blood Sugar

Angiotensin Converting Enzyme Inhibitors (ACE inhibitors) are also known to decrease insulin resistance in either type 1 or type 2 diabetic patients with concomitant hypertension [47]. Torlone et al. [48] demonstrated improved glycemic control in patients with arterial hypertension and type 2 diabetes using ACE inhibitors [48]. Insulin has a potent anti-inflammatory activity [32]. Insulin was found to be a rapid nonspecific and dose dependent inhibitors of the cytokine and glucocorticoids stimulation of acute phase protein, gene expression and exerted effect at the transcriptional levels. Insulin inhibition applied to all cell cytokines tested but to various degrees depending upon the particular acute phase gene [49]. 


\section{Current Research in Diabetes \& Obesity Journal}

In this study, of the 25 type 2 diabetic patients on treatment for at least 5 years, 8 patients were in sulfonylurea-metformin combination, 7 were on glitazone, 6 were on sulfonylurea alone, 2 were on glitazone-metformin combination and 2 were on metformin alone. When compared with newly diagnosed untreated group (Group II) the levels of $\alpha 1$-antitrypsin, $\alpha 1$ acid glycoprotein and ceruloplasmin were statistically lower. No significant difference was found in the fibrinogen levels. The values of $\alpha 1$-acid glycoprotein and ceruloplasmin were comparable to those of the control group. The RBS values were like those of untreated group (193.62 \pm 33.65 and 193.26 \pm 35.30$)$. It is interesting to note that $\alpha 1$-acid glycoprotein levels were almost the same in type 1 diabetes type 2 untreated patients and control (Table 2). Probably $\alpha 1$-acid glycoprotein is the most amenable acute phase protein to treatment modalities. Comparable ceruloplasmin levels in type 2 patients on treatment and controls again raise the question as to the 'prooxidant' or 'antioxidant' action of ceruloplasmin. No change in fibrinogen values suggest multiple pathway involvement that are poorly understood.

\section{References}

1. Fausi AS, Braunwald E, Isselbacher KJ, Wilson JD, Joseph BM, et al. Endocrinology and metabolism, Diabetes Mellitus. In: Harrison's Principle of Internal Medicine.

2. Pickup JC (2004) Inflammation and activated innate immunity in the pathogenesis of type 2 diabetes. Diabetes care 27(3) : 813-823.

3. Pickup JC, Crook MA (1997) Is type II diabetes mellitus a disease of the innate immune system: acute phase reactants and interleukin- 6 with metabolicsyndrome X. Diabetologia 41(10): 1241-1248.

4. Snijder MB, Dekker JM, Visser M, Stehouwer CDA, Van Hinsberg VWM et al. (2001) C-reactive protein and diabetes type 2. Diabetologia 44 (Suppl 1): 115A.

5. Spranger J, Kroke A, Mohlig M, Huffman K, Bergman MM, et al. (2003) Inflammatory cytokines and the risk to develop type 2 diabetes: results of the prospective population based European Prospective InvestigationCancer and Nutrition (EPICN)- Potsdam study. Diabetes 52(3): 812-818

6. Trinder P (1969) Determination of glucose in blood using glucose oxidase with an alternative oxygen acceptor. Ann Cli Biochem 6: 24 .

7. Varley H, Gowenlock AH, Bell M (1991) Determination of plasma fibrinogen. In: Practical Clin Biochem, (5 ${ }^{\text {th }}$ edn $)$, CBS publishers and Distributors, India, pp. 557-559.

8. Sunderman FW, Nomoto S (1970) Measurement of human serum ceruloplasmin by its p-phenylenediamine oxidase activity. Clin Chem 16(11): 903-910.

9. Sundaresh CS, Aroor AR, Pattabiraman TN (1978) Comparative study of amidolytic and caseinolytic methods for the determination of urinary trypsin inhibitor. Indian J Med Res 68: 341-44.

10. Winzler RJ (1955) Determination of serum $\alpha-1$ acid glycoprotein. In: Methods in Biochemical Analysis, Interscience Pub, New York, USA, 2 270

11. Pickup JC (2004) Inflammation and activated innate immunity in the pathogenesis of type 2 diabetes. Diabetes care 27(3) : 813-823.
12. McMillan DE (1989) Increased levels of acute phase serum proteins in diabetes: Metabolism 38(11): 1042-1046.

13. Festa A, D’Agostino R, Tracy RP, Haffner SM (2002) Elevated levels of acute phase proteins and plasminogen activator inhibitor 1 predict the development of type 2 diabetes: the insulin resistance atherosclerosis study. Diabetes 51(4): 1131-1137.

14. Ernst E, Resch KL (1993) Fibrinogen as a cardiovascular risk factor: A met analysis and review of the of the literature. Ann Intern Med 118(12): 956-963.

15. Barrazzani R, Kiwanuka E, Zanneti M, Cristini M, Vettore M, et al (2003) Insulin acutely increases fibrinogen production in individuals with type 2 diabetes but not in individuals without diabetes. Diabetes 52(7): 1851-1856.

16. Williams KV, Erbey JR, Becker D, Arslanian S, Ochad TJ (2000) Can clinical factors estimate insulin resistance in Type 1 diabetes. Diabetes 49(4): 626-632.

17. Goldstein IM, Kaplan HB, Edelson HS, Weissmann G (1979) Ceruloplasmin, A scavenger of Superoxide anion radicals. J Biol Chem 254(10): 4040-4045.

18. Allessandri G, Raju K, Gullino PM (1983) Mobilization of capillary endothelium in vitro induced by effectors of angiogenesis in vivo. Cancer Res 43(4): 1790-1797.

19. Telci A, Cakatay U, Salman S, Satman I, Sivus A (2000) Oxidative protein damage in early stage type 1 diabetic patients. Diabetes Res Clin Pract 50(3): 212-223.

20. Baynes JW (1991) Role of oxidative stress in development of complications of diabetes. Diabetes 40(4): 405-412.

21. Ehrenwald E, Chisoim GM, Fox PL (1994) Intact human ceruloplasmin oxidatively modifies low density lipoprotein. J Clin Invest 93(4): 14931501.

22. Starkebaum G, Harlan JM (1986) Endothelial cell injury due to copper catalyzed hydrogen peroxide generation from Homocysteine. J Clin Invest 77(4): 1370-1376.

23. Sriharan M, Angela JR, Maria LPO, Bruce BD, Sotes SM, et al. (2002) Total sialic acid and associated elements of the metabolic syndrome in women with and without previous gestational diabetes. Diabetes Care 25(8): 1331-1335.

24. Engstrom G, Stavenow L, Hedblad B, Lind P, Eriksson KF, et al. (2003) Inflammation sensitive plasma protein, diabetes mortality and incidence of myocardial infarction and stroke: A population based study. Diabetes 52(2): 442-446.

25. Schmidt MI, Duncan BB, Sharrett AR, Lindberg G, Savage PJ, et al. (1999) Markers of inflammation and prediction of diabetes mellitus in adult (Atherosclerosis Risk in Communities Study) : A Cohort Study. Lancet 353(9165): 1649-1652.

26. Duncan BB, Schmidt MI, Offen BS, Wu KK, Savage PJ, et al. (1999) Factor VIII and other hemostasis variables are related to incident diabetes in adult: The Atherosclerosis Risk in Community (ARIC) study. Diabetes Care 22(5): 767-772.

27. Pradhan AD, Manson JE, Ruai N, Buring JE, Ridker PM (2001) C-reactive protein, interleukin- 6 and risk of developing type 2 diabetes mellitus. JAMA 286(3): 327-334.

28. Gavella M, Lipovac V, Car A, Vocic M, Sokolić L, et al. (2003) Serum sialic acid in subjects with impaired glucose tolerance and in newly diagnosed type 2 diabetic patient. Acta Diabetologica 40(2): 95-100.

29. Pickup JC, Crooke MA (1998) Is type 2 diabetes mellitus a disease of the innate immune system? Diabetologia 41(10): 1241-1248. 


\section{Current Research in Diabetes \& Obesity Journal}

30. Grimble RF (2002) Inflammatory status and insulin resistance. Curr Opin Clin Nutr Metab Care 5(5): 551-559.

31. Pradhan AD, Ridkar PM (2002) Do atherosclerosis and type 2 diabetes share a common inflammatory basis? Eur Heart J 23(11): 831-834.

32. Mohammed Ali V, Goodrick S, Rawesh A, Katz DR, Miles JM, et al. (1997) Subcutaneous adipose tissue releases interleukin-6, but not tumor necrosis factor $\alpha$, in vivo. J Clin Endocrinol Metab 82(12): 4196-4200.

33. Hotamisligil GS, Amer P, Cam JF, Atkinson RL, Spiegelman BM (1998) Increased adipose tissue expression of tumor necrosis factor $\alpha$ in human obesity and insulin resistance. J Clin Invest 95(5): 2409-2415.

34. FriedSK, Budkin DA, Greenberg AS (1998) Omental and subcutaneous adipose tissues of obese subjects release interleukin-6: adipose tissue difference and regulation by glucocorticoids. J Clin Endocrinol Metab 83(3): 847-850.

35. Duncan BB, Schmidt MI, Pankow JS, Ballantyne CM, Couper D, et al (2003) Low grade inflammation and development of type2 diabetes: the atherosclerosis risk in communities study. Diabetes 52(7): 17991805.

36. Bayens JW, Thorpe SR (1999) Role of oxidative stress in diabetic complications: a new perspective on an old paradigm. Diabetes 48(1): $1-9$.

37. Brownlee M (2001) Biochemistry and molecular cell biology of diabetic complication. Nature 414(6865): 813-820.

38. Manford RS (2001) Statins and the acute phase response. N Engl J Med 344(26): 2016-2018.

39. Sparrow CP, BurtonCA, Hernandez M (2001) Simvastatin has antiinflammatory and antiatherosclerosis activities in depend of plasma cholesterol lowering. Arterioscler Thromb Vasc Biol 21(1): 115-121.

40. Freeman DJ, Norrie J, Satter N (2001) Pravastatin and the development of diabetes mellitus: evidence for a protective treatment in the West of Scotland Coronary Prevention Study. Circulation 103(3): 357-362.
41. Yuan M, Konstanopoulos N, Lee J, Hansen L, Li ZW, et al. (2001) Reversal of obesity and diet induced insulin resistance with salicylate or targeted disruption of ikkbeta. Science 293(5535): 1673-1677.

42. Hundal RS, Petersen KF, Mayerson AB, Randhawa PS, Inzucchi S, et al. (2002) Mechanism by which high dose aspirin improves glucose metabolism in type 2 diabetes. J Clin Invest 109(10): 1321-1326.

43. Ricole M, Li AC, Willison TM, Kelly CJ, Glass CK (1998) The peroxizome proliferators activated receptor(gamma) is a negative regulator of macrophage activation. Nature 391(6662): 79-82.

44. Haffner SM, Greenberg AS, Westor WM, Chen H, Williams K, et al (2002) Effect of rosiglitazone treatment on nontraditional markers of cardiovascular disease in patients with type 2 diabetes mellitus. Circulation 106(6): 679-684.

45. Chu NV, Kong APS, Kim DD, Armstrong D, Baxi S, et al. (2002) Differential effects of metformin and troglitazone on cardiovascular risk factors with type 2 diabetes: Diabetes Care 25(3): 542-549.

46. Ebeling P, Teppo AM, Koiestinen HA, Viikari J, Ronnemma T, et al. (1999) Troglitazone reduces hyperglycaemia and selective acute phase proteins in patients with type 2 diabetes. Diabetologia $42(12)$ 1433-1438.

47. Pollare T, Lithell H, Berne CA (1989) A comparison of the effects of hydrochlorothiazide and captopril on glucose and lipid metabolism in patients with hypertension. N Engl J Med 321(13): 866-872.

48. Torlone E, Britta M, Rambotti AM, Periello G, Santeusanio F, et al (1993) Improved glycemic control after long term angiotensin convertingenzyme inhibition in subjects with arterial hypertension and type 2 diabetes: Diabetes Care 16(10): 1347-1355.

49. Campus SP, Baumann H (1992) Insulin is a prominent modulator of the cytokine stimulated expression of acute phase plasma protein genes. Mol Cell Biol 12(4): 1789-1797.

\begin{tabular}{|l|}
\hline \multicolumn{1}{|c|}{ Your next submission with Juniper Publishers } \\
will reach you the below assets \\
- Quality Editorial service \\
- Swift Peer Review \\
- Reprints availability \\
- E-prints Service \\
- Manuscript Podcast for convenient understanding \\
- Global attainment for your research \\
- Manuscript accessibility in different formats \\
( Pdf, E-pub, Full Text, Audio) \\
- Unceasing customer service \\
Track the below URL for one-step submission \\
https://juniperpublishers.com/online-submission.php \\
\hline
\end{tabular}

